\title{
Decreasing Labor Pain through Sacralist Counter-pressure Therapy Using Tennis Ball in the Mother during the Labor Process
}

\author{
Sri Rejeki*, Enny Widayati, Machmudah Machmudah, Arief Yanto \\ Department of Nursing, Faculty of Health, Universitas Muhammadiyah Semarang, Semarang, Indonesia
}

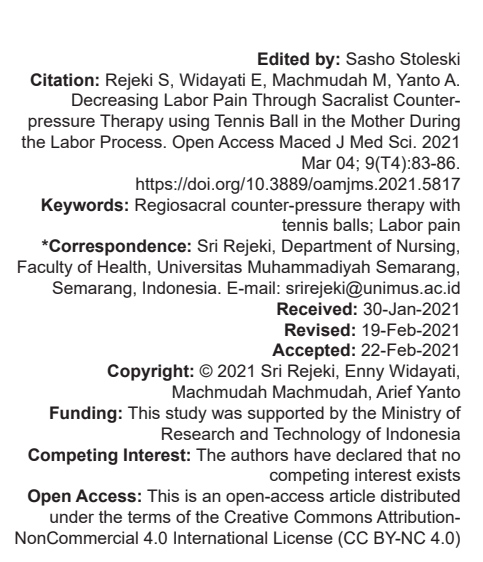

\begin{abstract}
BACKGROUND: Labor pain is a physiological process caused by the contraction of uterus muscle as an effort to open the cervix and push the baby's head toward the pelvis. One of the treatments giving by nurses to reduce the pain is by counter-pressure therapy.

AIM: The aim of the study was to determine the effect of counter-pressure therapy using tennis balls toward the pain level in the first stage during the active phase of labor.

METHODS: It was a quasi-experimental study with pretest-posttest one group design. The population in this study was patients with active phase I delivery in PKU Muhammadiyah Hospital of Temanggung. A total of 26 respondents were selected through purposive sampling technique. The data were analyzed using Wilcoxon matched paired test.

RESULTS: The pain intensity in 26 respondents $(100 \%)$ in the first stage during the active phase of labor before the treatment was categorized as severe pain. However, after the implementation of the counter-pressure therapy using tenis ball, the pain intensity was categorized as moderate in 18 respondents $(69.2 \%)$ and severe in the rest of the respondents $(30.8 \%)$
\end{abstract}

CONCLUSION: Counter-pressure massage therapy using a tennis ball was effective in reducing the level of pain in the first stage during the active phase of labor with a $p=0.000(\alpha<0.05)$.

\section{Introduction}

Every delivery is always accompanied by pain [1], [2]. This pain occurs due to the physiological process of childbirth in the form of uterine contractions to thin and open the uterine cervix and push the fetal head into the pelvis. During the first stage of the active labor phase, the pain is mainly caused by the physiological process of the cervical dilatation, uterine muscle hypoxia during the contraction, uterine corpus ischemia, lower uterine segment, and cervical nerve compression [3].

The pain of labor could be treated by pharmacological therapy such as anesthesia by an anesthetic expert or the non-pharmacological methods such as relaxation, imagery and visualization, or massage [4], [5].

One of the suggested massage techniques is a counter-pressure technique, which is very effective in reducing pain during phase I labor. Counter-pressure massage could counter pain transmission to the medulla spinalis and brain. The strong pressure given by the massage could activate endorphin from the halted pain transmission process and reduce the pain sensation in the synapses of the spinal cord and brain cells [6], [7], [8]. Pain stimulus could pass through the open-access of defense and stopped by the closed defense. The step in performing the therapy is by pressing the heel of the hand right above the tail bone or on the sacrum. Give a big pressure with a slightly circular movement [9].

The preliminary study found that $100 \%$ of labor patients in PKU Muhammadiyah Hospital of Temanggung experienced the pain of labor. About 15\% of the patients experienced light pain (during cervical opening 1-4), 35\% of the patients experienced moderate pain (cervix opening 5-6), and 45\% experienced severe pain (cervix opening 7-9). Most mothers cannot adjust to the pain during the uterine contraction. During that stage, mothers usually complain that they cannot hold the pain, screaming, and cannot accept pain coping. Based on the finding of the research above, the researcher was interested in applying counterpressure techniques to all of the mothers giving birth in PKU Muhammadiyah Hospital of Temanggung to reduce the pain of labor during the first stage of the active phase. Any kind of pain management for mothers in the first stage during the active phase of labor has not been applied in PKU Muhammadiyah Hospital of Temanggung. Therefore, the researcher was interested in applying counter-pressure massage using a tennis ball to reduce pain labor during the first stage during the active phase of labor. A tennis ball is very effective 
to massage the sacrum area. A tennis ball is handy and able to reach the sacrum area very well [9].

\section{Methods}

It was a quasi-experimental research with pretest-posttest one group design. The population in this research was all of the pregnant mothers during their first stage of the active phase in PKU Muhammadiyah Hospital of Temanggung, which were 26 respondents. The research instrument in the form of a standard operating procedure to reduce pain using counter-pressure using a tennis ball has been tested for its validity and reliability by experts. Meanwhile, pain before and after treatment was measured using the numeric rating scale (NRC). Counterpressure therapy with tennis balls is carried out 3 times in a row at 3 times of uterine contractions with a time of $40-50 \mathrm{~s}$ each treatment by trained personnel. This research is a quasi-experimental study with a pretest-posttest group design. The population in this study was all pregnant women in the first phase of the active phase at PKU Muhammadiyah Temanggung Hospital, amounting to 26 respondents. The research instrument in the form of a standard operating procedure to reduce pain using counter-pressure using a tennis ball has been tested for validity and reliability by experts. Meanwhile, pain before and after treatment was measured using a NRC. Counterpressure therapy with a tennis ball is carried out 3 times in a row, 3 times uterine contractions with a time of 40-50 s each treatment by trained personnel.

The research flow began with the selection of respondents based on inclusion criteria, namely mothers with normal deliveries, head location, single fetuses, no abnormalities, mature gestation period, and not receiving pain medications. Respondents were explained and gave consent for participation in the research (informed consent). Before and after the procedure, the level of labor pain will be measured. This research has received ethical approval at the Health Research Ethics Commission, Faculty of Public Health, Universitas Muhammadiyah Semarang with number: 337/KEPK-PKM/UNIMUS/2020 dated March 11, 2020. Meanwhile, the research was conducted during February-March 2020. The data were then analyzed using univariate and bivariate analysis of Wilcoxon's and paired t-test.

\section{Results}

The 26 respondents were characterized as age between 20 and 35 years old (Table 1), the education background of the respondents was from elementary school to bachelor. The respondents were mostly housewives and on their second pregnancy.

Based on Table 2, the educational background of the respondents was ranged from elementary school to a bachelor's degree. Education is one of the influential factors toward respondents' knowledge, as the higher the respondents' education, the easier they accept new information. For the occupation, most of the respondents were housewives. It means that they have more time to learn about pain reduction during labor and able to comfortably go through their labor process. Besides, most of the respondents were in their second pregnancy. Parity is quite influential to the pain intensity, based on the previous labor history. The mother in the first pregnancy might not know the pain during the labor yet.

The research finding showed that 26 respondents (100\%) experienced severe pain before the implementation of counter-pressure massage (Table 3 ). The pain scale ranged from 7 to 9 . However, after the implementation of the counter-pressure massage technique, 18 respondents $(69.2 \%)$ experienced moderate pain of which pain scale. Ranged from 4 to 6 and 8 patients $(30.8 \%)$ experienced severe pain with pain scale ranged from 7 to 9 .

Table 1: Respondents' age at PKU Muhammadiyah Hospital of Temanggung $(n=26)$

\begin{tabular}{lllll}
\hline Indicator & Median & Mode & SD & Min-Max \\
\hline Age & 27.50 & 32 & 4.928 & $20-35$ \\
\hline Source: Primary data $(2020)$ & & &
\end{tabular}

The research showed that 26 respondents experienced a significant decrease in the pain scale $(p=0.000)$ (Table 4). The comparative condition at -4.572 and the Wilcoxon's showed the $p=0.000<\alpha 0.05$. It means that Ho was rejected. It could be concluded that counterpressure massage could significantly decrease the pain intensity in the first stage during the active phase of labor.

Table 2: Respondents' characteristics at PKU Muhammadiyah Hospital of Temanggung $(n=26)$

\begin{tabular}{lll}
\hline Indicators & $\mathrm{f}$ & $\%$ \\
\hline Education & 5 & \\
$\quad$ Elementary school & 6 & 19.2 \\
Middle school & 7 & 23.1 \\
High school & 5 & 26.9 \\
Associate degree & 3 & 19.2 \\
Bachelor degree & 26 & 11.5 \\
$\quad$ Total & & 100.0 \\
Occupation & 10 & \\
Housewife & 4 & 38.5 \\
Teacher & 4 & 15.4 \\
Civil servant & 8 & 15.4 \\
Private employee & 26 & 30.8 \\
$\quad$ Total & 18 & 100.0 \\
Parity & 6 & 69.2 \\
Second pregnancy & 2 & 23.1 \\
Third pregnancy & 26 & 7.7 \\
Fourth pregnancy & & 100.0 \\
$\quad$ Total & &
\end{tabular}

\section{Discussion}

Theresearchfindingshowedthat 26 respondents $(100 \%)$ experienced severe pain before applying 
counter pressure with a tennis ball to the regiosacral massage area. However, after the implementation of the counter-pressure massage technique, 18 respondents $(69.2 \%)$ experienced moderate pain and eight patients $(30.8 \%)$ experienced severe pain. It means that the implementation of counter-pressure massage could decrease the pain scale. Another research mentioned that most of the respondents for counter pressure research experienced severe pain in the first stage during the active phase of labor [10].

The research found that the counter-pressure massage technique could effectively decrease the pain intensity in the first stage during the active phase of labor. This research finding was in line with the other research of which there was a significant difference between before and after the implementation of counter-pressure massage techniques to decrease the pain intensity in the first stage during the active phase of labor [6]. Therefore, it could be drawn that counterpressure massage could decrease pain intensity with the mean of the pain intensity decrease was 0.15385 .

Counter-pressure consists of constant strong push given to some points in the lower back during contractions, using hand fists, end of hand palms, or strong objects. The pressure may also be given in both thighs in the side parts using hands performed by health service helpers or providers [11], [12]. The counterpressure regiosacralis therapy has also been developed in the form of test instruments, in which the results are as effective as using the humans' physical power [13]. The working mechanisms from the procedures of counterpressure regiosacralis therapy are by blocking the pain message gate (Gate control theory) which will be delivered to the medulla spinalis and brain. Besides, the hands' pressures around the sacrum areas should be given when performing the counter-pressure techniques [14]. This theory states that pain impulses can be managed or even inhibited by the defending mechanisms along with the central nervous system. The pain impulses are delivered when a defense is opened and impulses are inhibited when a defense is blocked. The efforts to block the defense are the therapeutic principle to relieve the pain [15], [16], [17].

Counter-pressure is more effective in reducing the pain in the first stage during the active phase of labor. It could counter pain transmission to the medulla spinalis and brain. The strong pressure given by the massage could activate endorphin from the halted pain transmission process and reduce the pain sensation in the synapses of the spinal cord and brain cells [5], [18], [19]. The counter-pressure technique with a tennis ball is very effective in reducing the level of pain during stage I labor. Giving massage with a counter-pressure technique can close the gate of pain messages that will be delivered to the spinal cord and brain, with strong pressure on the tennis ball on the regiosacral will stimulate the compound endorphin. The activated endorphins provide a feeling of comfort. Strong pressure with the tennis ball causes the
Table 3: The pain intensity in the first stage during the active phase of labor before and after the implementation of counter-pressure massage technique at PKU Muhammadiyah Hospital Temanggung $(n=26)$

\begin{tabular}{lll}
\hline Indicator & Median & SD \\
\hline Pain intensity before the counter pressure & 8.00 & 0.613 \\
Pain intensity after the counter pressure & 6.00 & 0.849 \\
\hline Source: Primary data (2020). & &
\end{tabular}

transmission of pain messages to be inhibited and can reduce pain sensations that are in the synapses of the spinal cord and brain cells [6], [18]. Pain stimulation will be transmitted by open defenses and pain stimulation will be inhibited if a defense is closed.

Table 4: The effect of counter-pressure massage toward the paint intensity in the first stage during the active phase of labor

\begin{tabular}{lll}
\hline Indicators & Coefficient $(Z)$ & p-value \\
\hline Pain intensity before the & -4.572 & 0.000 \\
counter-pressure & & \\
Pain intensity after the & & \\
counter-pressure & & \\
\hline Source: Primary data (2020).
\end{tabular}

\section{Conclusion}

All of the respondents were within the productive age of 20-35 years old. It means that the age range was in the safe range to give birth and within the optimum reproductive health. Besides, most of the respondents were housewives. The pain experienced by the respondents during the phase I labor before the implementation of counter-pressure massage was severe. Meanwhile, after the implementation of counter-pressure massage, the pain intensity was decreased. Regiosacral counter-pressure with a tennis ball significantly reduces pain in the first stage during the active phase of labor.

\section{Suggestion}

This research is effective in decreasing pain intensity in the first stage during the active phase of labor. Therefore, the patients are expected to be cooperative and voluntarily ready to be the respondents of the counter-pressure massage technique. The technique could be applied as one of the non-pharmacological comprehensive nursing interventions to reduce the pain in the first stage of labor. Either nurse or midwife who provides nursing intervention is expected to be the guidance or parameters in developing nursing science, especially in maternity nursing.

Further research could be conducted related to the other non-pharmacological therapy to cope or decrease pain intensity in the phase I labor, for instance, by combining murottal therapy or aromatherapy intervention while performing counter-pressure massage. 


\section{Acknowledgment}

We would like to acknowledge the Directorate of Research and Community Service, The Ministry of Research and Technology of Indonesia that has funded this research. We would also like to express our appreciation to all patients who participated in this study and the nurses in PKU Muhammadiyah Hospital of Temanggung who provided valuable assistance during data collection.

\section{References}

1. Ashagrie HE, Fentie DY, Kassahun HG. A review article on epidural analgesia for labor pain management: A systematic review. Int J Surg Open. 2020;24:100-4. https://doi.org/10.1016/j. ijso.2020.04.007

2. Orr PM, Shank BC, Black AC. The role of pain classification systems in pain management. Crit Care Nurs Clin North Am. 2017;29(4):407-18. https://doi.org/10.1016/j.cnc.2017.08.002 PMid:29107304

3. Lee GI, Neumeister MW. Pain: Pathways and physiology. Clin Plast Surg. 2020;47(2):173-80.

PMid:32115044

4. Herinawati $\mathrm{H}$, Hindriati $\mathrm{T}$, Novilda A. The Effect of Effleurage Massage on Stage I Labor Pain in the Active Phase in the Independent Practice of Midwives Nuriman Rafida and the Independent Practice of Midwife Latifah Jambi City in 2019. J IIm Univ Batanghari Jambi. 2019;19:590-601. https://doi. org/10.33087/jiubj.v19i3.764

5. Hensley JG, Collins MR, Leezer CL. Pain management in obstetrics. Crit Care Nurs Clin North Am. 2017;29(4):471-85. PMid:29107309

6. Farida S, Sulistiyanti A. Metode Counterpressure Sebagai Upaya Untuk Mengurangi Nyeri Persalinan Kala I, SMIKNAS; 2019. p. 217-22.

7. Alimoradi Z, Kazemi F, Gorji M, Valiani M. Effects of ear and body acupressure on labor pain and duration of labor active phase: A randomized controlled trial. Complement Ther Med. 2020;51:102413. https://doi.org/10.1016/j.ctim.2020.102413

\section{PMid:32507430}

8. Raana HN, Fan XN. The effect of acupressure on pain reduction during first stage of labour: A systematic review and metaanalysis. Complement Ther Clin Pract. 2020;39:101126. https:// doi.org/10.1016/j.ctcp.2020.101126

PMid:32379664

9. Paseno $M$, Situngkir R, Pongantung $H$, Wulandari $F$, Astria $D$, Wulandari $F$, et al. Massage counter pressure and massage effleurage effectively reduce labor pain. J IIm Perawat Manad. 2019;7:20-32. https://doi.org/10.47718/jpd.v7i1.797

10. Satria M. Pengaruh Sebelum dan Sesudah Dilakukan Pijat Punggung Teknik Counterpressure Terhadap Pengurangan Rasa Nyeri lbu Bersalin Kala I Fase Aktif Di Klinik Bidan Elviana Tahun 2017, Menara IImu; 2018. p. 12. https://doi.org/10.33860/ jik.v12i02.108

11. Stillerman E. A Midwife's Touch; 2008.

12. Levett KM, Smith CA, Dahlen HG, Bensoussan A. Acupuncture and acupressure for pain management in labour and birth: $A$ critical narrative review of current systematic review evidence. Complement Ther Med. 2014;22(3):523-40. https://doi. org/10.1016/j.ctim.2014.03.011 PMid:24906592

13. Rejeki RM. Bagus SI. Tingkat Nyeri Persalinan Kala I Persalinan Melalui Terapi Alat Mekanik Manual Regio Sakralis, Pros Semin Nas; 2012.

14. Bobak IM. Buku Ajar Keperawatan Maternitas. $4^{\text {th }}$ ed. Jakarta: EGC; 2004.

15. Potter PA, Perry AG, Stockert P, Hall A. Fundamental of Nursing E-Book. Netherlands: Elsevier; 2016.

16. Braz J, Solorzano C, Wang X, Basbaum Al. Transmitting pain and itch messages: A contemporary view of the spinal cord circuits that generate gate control. Neuron. 2014;82(3):522-36. https://doi.org/10.1016/j.neuron.2014.01.018 PMid:24811377

17. Murray SS, McKinney ES. Foundations of Maternal-Newborn and Women's Health Nursing. $6^{\text {th }}$ ed. St. Louis, Missouri: Elsevier; 2014

18. Rodriguez L. Pathophysiology of pain: Implications for perioperative nursing. AORN J. 2015;101(3):338-44 PMid:25707726

19. DanhakI V, Miltiades A, Ing C, Chang B, Edmondson D, Landau R et al. Observational study evaluating obstetric anesthesiologist residents' well-being, anxiety and stress in a North American academic program. Int J Obstet Anesth. 2019;38:75-82. https:// doi.org/10.1016/j.ijoa.2018.10.011

PMid:30509676 